University of Nebraska - Lincoln

DigitalCommons@University of Nebraska - Lincoln

\title{
Unprecedented last-glacial mass accumulation rates determined by luminescence dating of loess from western Nebraska
}

\author{
Helen M. Roberts \\ University of Wales, hmr@aber.ac.uk \\ Daniel R. Muhs \\ U.S. Geological Survey, dmuhs@usgs.gov \\ Ann G. Wintle \\ University of Wales \\ Geoff A. T. Duller \\ University of Wales \\ E. Arthur Bettis III \\ University of lowa, art-bettis@uiowa.edu
}

Follow this and additional works at: https://digitalcommons.unl.edu/usgsstaffpub

Part of the Earth Sciences Commons

Roberts, Helen M.; Muhs, Daniel R.; Wintle, Ann G.; Duller, Geoff A. T.; and Bettis, E. Arthur III, "Unprecedented last-glacial mass accumulation rates determined by luminescence dating of loess from western Nebraska" (2003). USGS Staff -- Published Research. 176.

https://digitalcommons.unl.edu/usgsstaffpub/176

This Article is brought to you for free and open access by the US Geological Survey at DigitalCommons@University of Nebraska - Lincoln. It has been accepted for inclusion in USGS Staff -- Published Research by an authorized administrator of DigitalCommons@University of Nebraska - Lincoln. 


\title{
Unprecedented last-glacial mass accumulation rates determined by luminescence dating of loess from western Nebraska
}

\author{
Helen M. Roberts, ${ }^{\mathrm{a}, *}$ Daniel R. Muhs, ${ }^{\mathrm{b}}$ Ann G. Wintle, ${ }^{\mathrm{a}}$ Geoff A.T. Duller, ${ }^{\mathrm{a}}$ \\ and E. Arthur Bettis $\mathrm{III}^{\mathrm{c}}$ \\ ${ }^{a}$ Institute of Geography and Earth Sciences, University of Wales, Aberystwyth SY23 3DB, UK \\ ${ }^{\mathrm{b}}$ U.S. Geological Survey, MS 980, Box 25046, Federal Center, Denver, CO 80225, USA \\ ${ }^{\mathrm{c}}$ Department of Geoscience, University of Iowa, Iowa City, IA 52242, USA
}

Received 14 August 2002

\begin{abstract}
A high-resolution chronology for Peoria (last glacial period) Loess from three sites in Nebraska, midcontinental North America, is determined by applying optically stimulated luminescence (OSL) dating to 35-50 $\mu \mathrm{m}$ quartz. At Bignell Hill, Nebraska, an OSL age of 25,000 yr near the contact of Peoria Loess with the underlying Gilman Canyon Formation shows that dust accumulation occurred early during the last glacial maximum (LGM), whereas at Devil's Den and Eustis, Nebraska, basal OSL ages are significantly younger (18,000 and 21,000 yr, respectively). At all three localities, dust accumulation ended at some time after 14,000 yr ago. Mass accumulation rates (MARs) for western Nebraska, calculated using the OSL ages, are extremely high from 18,000 to 14,000 yr-much higher than those calculated for any other pre-Holocene location worldwide. These unprecedented MARs coincide with the timing of a mismatch between paleoenvironmental evidence from central North America, and the paleoclimate simulations from atmospheric global circulation models (AGCMs). We infer that the high atmospheric dust loading implied by these MARs may have played an important role, through radiative forcing, in maintaining a colder-than-present climate over central North America for several thousand years after summer insolation exceeded present-day values.

(C) 2003 Elsevier Science (USA). All rights reserved.
\end{abstract}

Keywords: Dust flux; Peoria Loess; Optically stimulated luminescence dating; OSL; Quartz; Coarse-silt-sized grains; Mass accumulation rate (MAR); Climate forcing

\section{Introduction}

Midcontinental North America has the thickest deposits of last-glacial loess in the world, referred to as Peoria Loess. These loess deposits contain important records of variations in atmospheric dust, providing evidence which may be used to assess the role of dust in climate change. On the basis of thickness alone, the accumulation rates for these deposits are expected to be high, but little is actually known of the fluctuation in dust accumulation rates both during the last glacial period $(\sim 70,000-10,000 \mathrm{yr}$ ago $)$, and spatially across North America. A reliable, high-resolution chronol-

* Corresponding author. Fax: +44-1970-622659.

E-mail address: hmr@aber.ac.uk (H.M. Roberts). ogy is fundamental to any study of past dust accumulation. However, the existing chronology available for the loess deposits is based primarily on radiocarbon dating of paleosols that bracket all or most of the period of dust accumulation. Using the radiocarbon ages from paleosols gives only an average mass accumulation rate for the package of loess that they bracket, and any dust flux calculation based on these ages implicitly assumes that the accumulation rate has remained essentially constant over the period of deposition. In order to examine the temporal variation in dust accumulation, it is necessary to determine a chronology for the mineral grains that make up the loess deposit.

Luminescence dating is ideally suited to the investigation of the records of dust accumulation contained in loess as it is applied directly to the mineral component of the sediment 
itself. In contrast, radiocarbon dating must be applied to organic matter and relies upon sufficient material being preserved in the sediment. Very few luminescence ages have been published for midcontinental North America, and worldwide the majority of published luminescence ages for loess deposits are based on measurements of thermoluminescence (TL). However, since the event being dated is the last exposure of the sediment grains to light, optically stimulated luminescence (OSL-also referred to as optical dating (Aitken, 1998)) can provide higher precision ages for loess.

The chronologic information available for midcontinental North American loess deposits has been summarized by Bettis et al. (2003), who calculated mass accumulation rates (MARs) where possible, based largely on radiocarbon dating of paleosols. Eolian mass accumulation rates (MARs) can be calculated for the last glacial period based on data from loess deposits, dust in ice cores, and the eolian component of deep-sea sediments (see summaries in Kohfeld and Harrison, 2000, 2001; Mahowald et al., 1999; Sun et al., 2000). Bettis et al. (2003) found MARs of $>3000 \mathrm{~g} \mathrm{~m}^{-2}$ $\mathrm{yr}^{-1}$ for midcontinental North America, a value that is high compared with those for most other continents e.g. $>1000$ $\mathrm{g} \mathrm{m}^{-2} \mathrm{yr}^{-1}$ for the Chinese Loess Plateau (Sun et al., 2000). The values calculated represent average accumulation rates for last-glacial dust deposition; if dust deposition rates varied over this time period, then specific MARs could actually be even higher. This study targets three of the thickest last-glacial loess deposits in the North American mid-continent, using high-resolution luminescence dating to determine a chronology for the loess, thus enabling the calculation of more accurate MARs, to examine the temporal variations in last-glacial dust flux.

\section{Study area}

Loess is areally the most important surficial deposit in central North America. Although loess is typically associated with areas close to rivers that drained the Laurentide Ice Sheet, it is also distributed widely over the central Great Plains of Nebraska, Kansas, and Colorado (Fig. 1) where much of it is derived from nonglacial sources (Aleinikoff et al., 1998, 1999). Three late Quaternary loess units, from oldest to youngest, the Gilman Canyon Formation, and the Peoria and Bignell Loesses, have been identified and correlated on the Great Plains. The Gilman Canyon Formation (dated to 40,000-22,000 cal yr B.P., Johnson, 1993; Maat and Johnson, 1996; Martin, 1993; Muhs et al., 1999) is overlain by Peoria Loess. Peoria Loess was deposited during the late Wisconsin period and is the thickest (up to $\sim 48$ m) and areally most extensive North American loess unit. On the central Great Plains it is capped by a dark, organicrich buried soil (the Brady Soil) separating it from the overlying Holocene Bignell Loess. In this study, three thick, last-glacial loess exposures in Nebraska were investigated (Fig. 1): Bignell Hill (48 m Peoria Loess, with $\sim 25 \mathrm{~m}$ exposed); Devil's Den (30 m Peoria Loess exposed); and Eustis (16 m Peoria Loess exposed).

\section{Methods}

\section{Sample collection and preparation}

At each site, samples were taken for luminescence dating using thin-walled cylindrical corers driven into the face of the section, or by carving out loess blocks. Samples were taken from the Peoria Loess, close to the paleosols that bracket this deposit, and throughout the deposit itself.

In the laboratory, 13 samples were prepared for luminescence dating using standard procedures (e.g., Roberts and Wintle, 2001), except that the 35- to 50- $\mu$ m fraction was isolated by wet sieving. This grain-size fraction was selected as being more appropriate than the 4- to $11-\mu \mathrm{m}$ grain size typically used for dating loess deposits since the Peoria Loess in the central Great Plains contains abundant coarse silt (Swineford and Frye, 1951; Muhs and Bettis, 2000; Muhs et al., 1999).

The mineral selected for optically stimulated luminescence dating was quartz, as this avoids a type of signal instability called anomalous fading, which is associated with feldspars (e.g., Aitken, 1998). To remove feldspars and isolate pure quartz, the 35 - to $50-\mu \mathrm{m}$ fraction was treated for 7 days using fluorosilicic acid in a ratio of $40 \mathrm{ml} \mathrm{35 \%}$ $\mathrm{H}_{2} \mathrm{SiF}_{6}: 1 \mathrm{~g}$ sediment (Berger et al., 1980), followed by a 45-min treatment with hydrochloric acid (37\%). The $\mathrm{H}_{2} \mathrm{SiF}_{6}$-treated material was then resieved at $35 \mu \mathrm{m}$. This fluorosilicic acid treatment produced pure quartz of 35-50 $\mu \mathrm{m}$ in diameter, suitable for luminescence dating. This quartz fraction was then dry-sieved through $50-\mu \mathrm{m}$ mesh onto 1-cm-diameter aluminum discs having a light cover of Silkospray. ${ }^{1}$

\section{Luminescence measurement}

The equivalent dose $\left(D_{\mathrm{e}}\right)$ was determined using a modified single-aliquot regenerative-dose (SAR) procedure (Banerjee et al., 2001; Roberts and Wintle, 2001) applied to quartz grains of $35-50 \mu \mathrm{m}$ in diameter. This procedure involves using thermal pretreatments from 160 to $300^{\circ} \mathrm{C}$ for $10 \mathrm{~s}$ (to isolate stable OSL signals), and stimulation with an infrared (IR)-emitting laser diode at $830-\mathrm{nm}$ wavelength to deplete the OSL signal from any feldspar remaining following chemical treatment, prior to stimulation with blue lightemitting diodes (LEDs) at $470 \mathrm{~nm}$ to obtain the [post-IR] OSL signal from quartz. This SAR procedure corrects for any luminescence sensitivity changes that may have occurred during burial, or caused by laboratory thermal pre-

\footnotetext{
${ }^{1}$ Use of trade names is for descriptive purposes only and does not imply endorsement by the U.S. Geological Survey.
} 


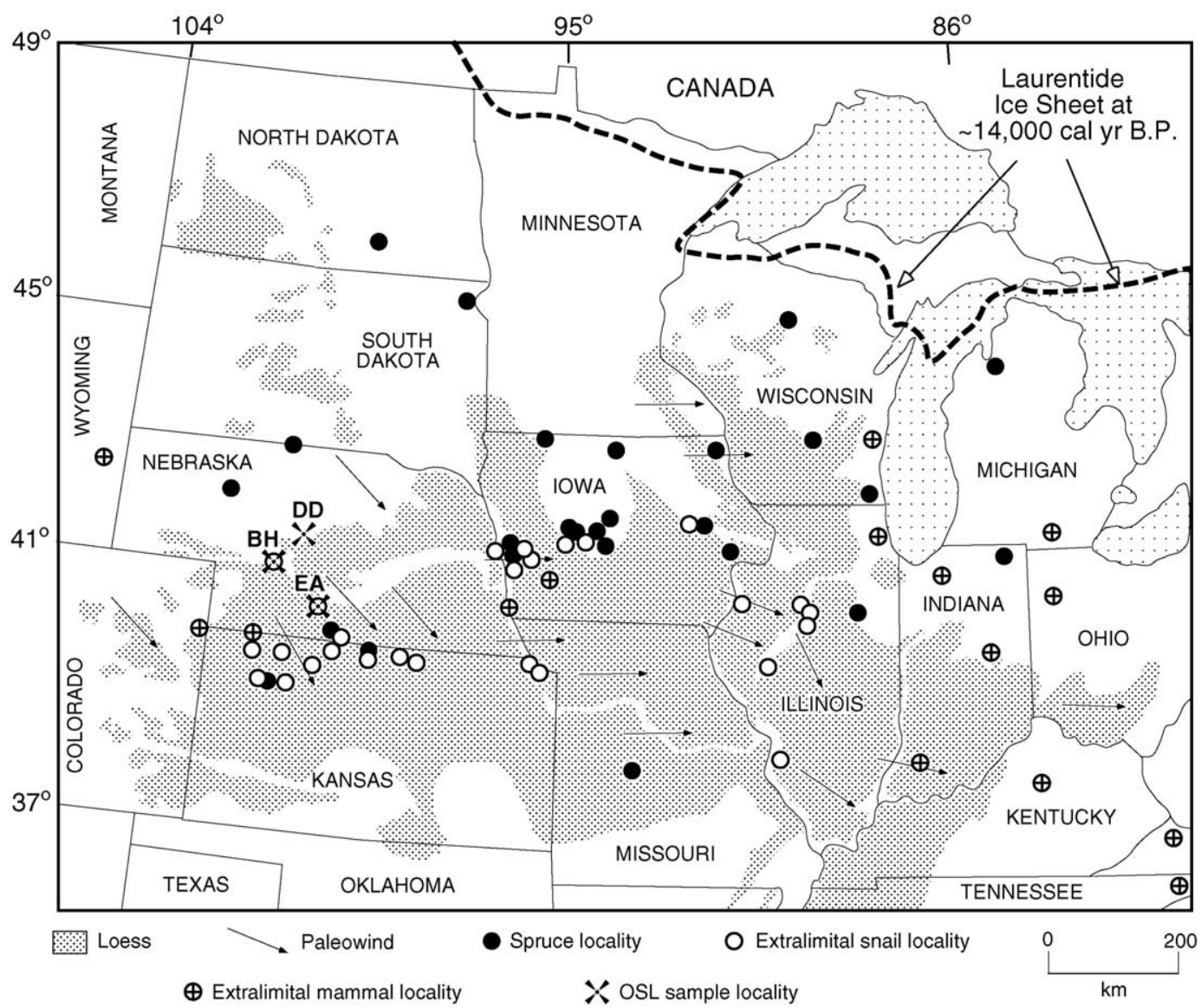

Fig. 1. Map showing the distribution of loess and inferred paleowinds in central North America and OSL sample localities (DD, Devil's Den; BH, Bignell Hill, EA, Eustis). Also shown for the late-glacial period are the estimated position of the Laurentide Ice Sheet (Licciardi et al., 1998), late-glacial localities with spruce macrofossils or pollen records dominated by spruce (Baker et al., 1992; Ruhe, 1969; Swinehart et al., 1994; Watts, 1983; Webb et al., 1983; Wells and Stewart, 1987), late-glacial loess localities with extralimital northern and western (i.e., cool climate) fossil land snails (Baker et al., 1986; Frye et al., 1974; Leonard, 1951; Leonard and Frye, 1960; Rousseau and Kukla, 1994; Ruhe, 1969; Wells and Stewart, 1987), and localities with extralimital northern mammals (FAUNMAP, 1994). Northern and western extralimital land snails include the species Vertigo modesta, Columella alticola, and Pupilla blandi, all of which do not occur in the central Great Plains region today, but have Cordilleran-boreal affinities (Lauriol et al., 2002). Extralimital northern mammals include the species Sorex arcticus, Rangifer tarandus, Tamias minimus, Microtus xanthognathus, Phenacomys intermedius, and Synaptomys borealis, all of whose present distributions are limited to tundra, boreal forest, or Cordilleran regions (FAUNMAP, 1994).

treatments. Luminescence measurements were made using an automated Risø TL/OSL reader, equipped with a beta source for irradiations, and blue LEDs $(470 \mathrm{~nm})$ providing approximately $17 \mathrm{~mW} \mathrm{~cm}^{-2}$ power density. The OSL measurements were made at $125^{\circ} \mathrm{C}$ and detected using three 3-mm Hoya U-340 filters (275-390 nm at 1\% cut, based on manufacturer's specifications).

\section{Dose-rate determinations}

Both field and laboratory measurements of uranium, thorium, and potassium were conducted. In situ radioactivity measurements were made for each sample using a portable gamma spectrometer. In the laboratory, thick-source alpha counting (TSAC) and beta counting using Ris $\varnothing$ GM-25-5 equipment were undertaken on dried bulk powder. The cosmic-ray dose rate was estimated for each sample as a function of depth, altitude, and geomagnetic latitude (Pres- cott and Hutton, 1994). The water content was assessed in the laboratory using sealed field samples, taken both from the face of the exposure and at depth from deep coring. Alpha and beta contributions to the dose rate were corrected for grain-size attenuation (Aitken, 1985).

\section{Chronology and dust deposition rates}

The OSL ages of the three loess sections are consistent with previous age determinations (Fig. 2). For each of the 13 samples, a minimum of 17 aliquots (each aliquot giving rise to an independent determination of $D_{\mathrm{e}}$ ) was used to determine the mean estimate of $D_{\mathrm{e}}$ used in the calculation of the final OSL age (Table 1). The uncertainty on $D_{\mathrm{e}}$ was calculated as the standard error of the mean. Within these uncertainties, the OSL ages are stratigraphically consistent (Fig. 2) and agree with previous radiocarbon ages for the 


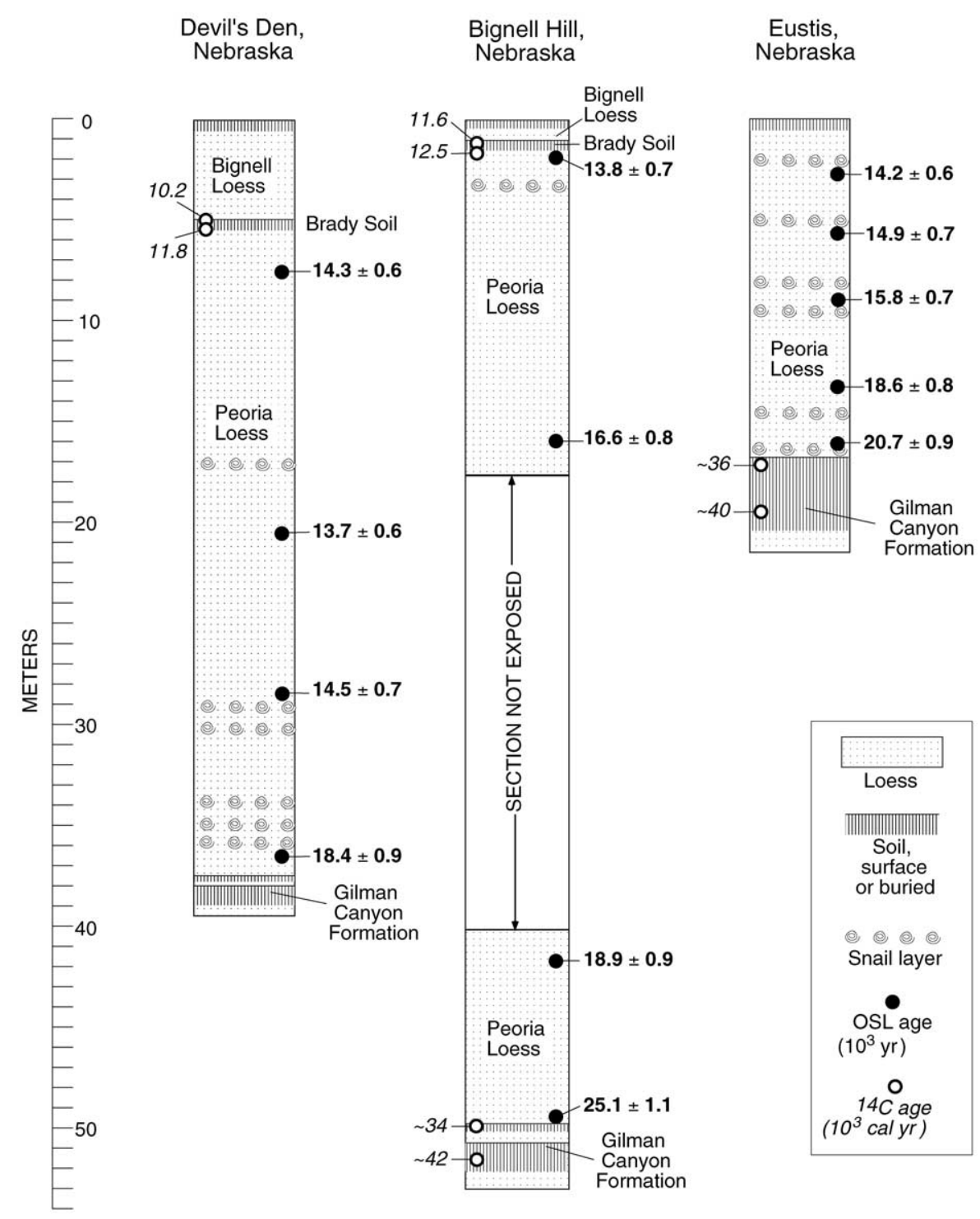

Fig. 2. Stratigraphy and OSL ages (on right side of each column) from the present study of three loess sections from the central Great Plains. Previously reported radiocarbon ages (Muhs et al., 1999; Maat and Johnson, 1996; Johnson and Willey, 2000) have been calibrated to "calendar" years (Stuiver et al., 1998; Voelker et al., 2000).

bracketing Brady Soil and Gilman Canyon Formation (Muhs et al., 1999; Maat and Johnson, 1996; Johnson and Willey, 2000). The OSL ages are also in agreement with previous TL ages (Maat and Johnson, 1996; Pye et al., 1995), but have much greater precision.

At Bignell Hill, an OSL age of 25,000 yr near the contact of Peoria Loess with the underlying Gilman Canyon Formation shows that dust accumulation began early in the last-glacial maximum. This is much earlier than is recorded at Eustis or at Devil's Den, where basal OSL ages are 21,000 and 18,000 yr, respectively (Fig. 2). The Brady Soil, which marks the end of Peoria Loess deposition and separates it from the overlying Holocene Bignell Loess, is not found at Eustis. However, at all three sites, the uppermost OSL ages show that Peoria Loess deposition effectively ceased shortly after $\sim 14,000$ yr ago (Fig. 2).
From Figure 2, it can be seen that the maximum dust accumulation occurred between $\sim 18,000$ to 14,000 yr ago We can calculate mass accumulation rates (MARs) for the loess deposits over this time interval, which enables comparison between the three sites. MARs were calculated based on the central values for the OSL ages and assuming a typical bulk density for Peoria Loess of $1.45 \mathrm{~g} \mathrm{~cm}^{-3}$ (Bettis et al., 2003). The average mass accumulation rates over the period from $\sim 18,000$ to $14,000 \mathrm{yr}$ ago are extremely high, being $\sim 11500 \mathrm{~g} \mathrm{~m}^{-2} \mathrm{yr}^{-1}$ for Bignell Hill, $\sim$ $10500 \mathrm{~g} \mathrm{~m}^{-2} \mathrm{yr}^{-1}$ for Devil's Den, and $\sim 3500 \mathrm{~g} \mathrm{~m}^{-2} \mathrm{yr}^{-1}$ for Eustis. These values are one to two orders of magnitude higher than those calculated for last-glacial eolian silt in New Zealand and Europe where average values range from $\sim 60$ to 300 and 300 to $1400 \mathrm{~g} \mathrm{~m}^{-2} \mathrm{yr}^{-1}$, respectively (calculations are based on data from Antoine et al., 2001; 
Table 1

Equivalent dose $\left(D_{\mathrm{e}}\right)$, dose rates, and luminescence ages

\begin{tabular}{|c|c|c|c|c|c|c|c|c|c|c|c|c|c|c|}
\hline $\begin{array}{l}\text { Sample } \\
\text { No. }^{{ }^{a}}\end{array}$ & $\begin{array}{l}\text { Depth } \\
\text { (m) }\end{array}$ & $D_{\mathrm{e}}(\mathrm{Gy})$ & $n^{\mathrm{b}}$ & $\mathrm{U}(\mathrm{ppm})^{\mathrm{c}}$ & Th $(\mathrm{ppm})^{\mathrm{c}}$ & $\mathrm{K}(\%)^{\mathrm{c}}$ & $\begin{array}{l}\text { Infinite } \\
\alpha \text { dose } \\
\text { rate }^{\mathrm{d}}\end{array}$ & $\begin{array}{l}\text { Infinite } \\
\beta \text { dose } \\
\text { rate }^{\mathrm{d}}\end{array}$ & $\begin{array}{l}\text { External } \\
\alpha \text { dose } \\
\text { rate "wet"d }\end{array}$ & $\begin{array}{l}\text { External } \\
\beta \text { dose } \\
\text { rate } \\
\text { "wet"d }\end{array}$ & $\begin{array}{l}\text { External } \\
\gamma \text { dose } \\
\text { rate } \\
\text { "wet"d }\end{array}$ & Cosmic $^{\mathrm{d}}$ & $\begin{array}{l}\text { Total } \\
\text { dose rate }^{\mathrm{d}}\end{array}$ & $\begin{array}{l}\text { Age } \\
\left(10^{3} \mathrm{yr}\right)^{\mathrm{e}}\end{array}$ \\
\hline 58DD1 & 7.30 & $49.4 \pm 0.6$ & 21 & $3.11 \pm 0.10$ & $9.48 \pm 0.3$ & $1.95 \pm 0.08$ & 15.6 & 2.24 & 0.277 & 1.92 & 1.15 & 0.118 & $3.46 \pm 0.14$ & $14.3 \pm 0.6^{\mathrm{f}}$ \\
\hline $58 \mathrm{DD} 2$ & 20.30 & $50.4 \pm 0.6$ & 20 & $3.36 \pm 0.11$ & $10.3 \pm 0.3$ & $2.11 \pm 0.08$ & 16.9 & 2.42 & 0.301 & 2.08 & 1.24 & 0.047 & $3.67 \pm 0.15$ & $13.7 \pm 0.6$ \\
\hline $58 \mathrm{DD} 3$ & 28.50 & $50.1 \pm 0.9$ & 22 & $3.46 \pm 0.11$ & $10.1 \pm 0.3$ & $1.87 \pm 0.07$ & 17.0 & 2.24 & 0.303 & 1.93 & 1.19 & 0.031 & $3.45 \pm 0.14$ & $14.5 \pm 0.7$ \\
\hline $58 \mathrm{DD} 4$ & 36.55 & $66.1 \pm 1.5$ & 23 & $3.26 \pm 0.10$ & $10.8 \pm 0.3$ & $2.03 \pm 0.08$ & 17.0 & 2.36 & 0.303 & 2.02 & 1.24 & 0.021 & $3.59 \pm 0.15$ & $18.4 \pm 0.9^{f}$ \\
\hline 44BH47 & 1.90 & $49.9 \pm 1.0$ & 37 & $2.94 \pm 0.12$ & $10.0 \pm 0.4$ & $2.03 \pm 0.10$ & 15.5 & 2.29 & 0.276 & 1.97 & 1.17 & 0.196 & $3.61 \pm 0.15$ & $13.8 \pm 0.7^{\mathrm{f}}$ \\
\hline 44BH60 & 15.90 & $58.0 \pm 0.9$ & 38 & $3.18 \pm 0.13$ & $10.1 \pm 0.4$ & $1.97 \pm 0.10$ & 16.2 & 2.28 & 0.289 & 1.96 & 1.18 & 0.063 & $3.49 \pm 0.15$ & $16.6 \pm 0.8$ \\
\hline 44BH46 & 41.65 & $70.7 \pm 1.2$ & 56 & $3.83 \pm 0.14$ & $10.8 \pm 0.4$ & $2.04 \pm 0.10$ & 18.56 & 2.45 & 0.330 & 2.10 & 1.30 & 0.017 & $3.75 \pm 0.16$ & $18.9 \pm 0.9^{f}$ \\
\hline 44BH37 & 49.50 & $87.6 \pm 1.7$ & 34 & $3.13 \pm 0.09$ & $11.8 \pm 0.3$ & $1.89 \pm 0.07$ & 17.4 & 2.26 & 0.309 & 1.94 & 1.24 & 0.013 & $3.50 \pm 0.14$ & $25.1 \pm 1.1$ \\
\hline 57EA1 & 2.50 & $55.2 \pm 0.8$ & 40 & $3.47 \pm 0.11$ & $11.1 \pm 0.3$ & $2.09 \pm 0.08$ & 17.78 & 2.44 & 0.316 & 2.10 & 1.28 & 0.182 & $3.88 \pm 0.16$ & $14.2 \pm 0.6^{\mathrm{f}}$ \\
\hline 57EA2 & 5.50 & $56.8 \pm 1.2$ & 19 & $3.55 \pm 0.11$ & $10.8 \pm 0.3$ & $2.07 \pm 0.08$ & 17.8 & 2.43 & 0.317 & 2.09 & 1.27 & 0.138 & $3.82 \pm 0.15$ & $14.9 \pm 0.7$ \\
\hline 57EA3 & 9.00 & $58.9 \pm 0.7$ & 17 & $3.69 \pm 0.12$ & $10.6 \pm 0.3$ & $2.00 \pm 0.08$ & 18.0 & 2.39 & 0.320 & 2.05 & 1.26 & 0.102 & $3.74 \pm 0.15$ & $15.8 \pm 0.7$ \\
\hline 57EA4 & 13.15 & $69.1 \pm 1.1$ & 20 & $3.46 \pm 0.11$ & $10.9 \pm 0.3$ & $2.05 \pm 0.08$ & 17.6 & 2.41 & 0.313 & 2.06 & 1.26 & 0.075 & $3.72 \pm 0.15$ & $18.6 \pm 0.8^{\mathrm{f}}$ \\
\hline 57EA5 & 16.00 & $77.6 \pm 1.4$ & 46 & $3.36 \pm 0.10$ & $11.6 \pm 0.4$ & $2.06 \pm 0.08$ & 17.8 & 2.42 & 0.318 & 2.08 & 1.29 & 0.061 & $3.74 \pm 0.15$ & $20.7 \pm 0.9$ \\
\hline
\end{tabular}

a Aberystwyth Luminescence Laboratory sample codes: Aber/58DD, Devil's Den; Nebraska; Aber/44BH, Bignell Hill, Nebraska; Aber/57EA, Eustis, Nebraska.

${ }^{\mathrm{b}} n$ is the number of $D_{\mathrm{e}}$ determinations.

${ }^{\mathrm{c}}$ Concentrations of $\mathrm{U}$, Th, and $\mathrm{K}$ were determined from in situ measurements using a portable gamma spectrometer and are shown to 3 significant figures.

${ }^{\mathrm{d}}$ Dose-rate values $\left(\mathrm{Gy} / 10^{3} \mathrm{yr}\right.$ ) have been rounded to 3 significant figures, but the total dose rates and ages have been calculated using values prior to rounding. Dose rates were calculated assuming a water content (expressed as \% dry mass) of $10 \pm 5 \%$, and using an $a$ value of $0.040 \pm 0.002$ (Rees-Jones, 1995). Central values are given for dose rates-errors are incorporated into that given for the total dose rate.

${ }^{\mathrm{e}}$ Luminescence ages are expressed as thousands of years before A.D. 2000, and calculated to 1 decimal place.

${ }_{\mathrm{f}}^{\mathrm{f}}$ Denotes the luminescence ages used to calculate mass accumulation rates (MARs) discussed in the text.

Eden et al., 1992; Hatté et al., 1998; Musson and Wintle, 1994; Nawrocki et al., 1999; Palmer and Pillans, 1996; Pillans et al., 1993; Sümegi and Rudner, 2001; Wintle et al., 1984). These mid-continental North American rates are even higher than those calculated for the Chinese Loess Plateau, where MARs range from 50 to $>1000 \mathrm{~g} \mathrm{~m}^{-2} \mathrm{yr}^{-1}$ (Sun et al., 2000).

The only other locality of which we are aware that has a MAR comparable to those we calculated for Nebraska is near the Delta River in central Alaska. At a single locality, Péwé (1975) reported a very high rate of dust accumulation during the Holocene, giving a MAR of $2900 \mathrm{~g} \mathrm{~m}^{-2} \mathrm{yr}^{-1}$. However, detailed mapping in this area shows that loess thicknesses diminish very rapidly to between approximately 1 and $3 \mathrm{~m}$ within 1-2 km downwind from the Delta River valley, the dust source (Lindholm et al., 1959; Péwé and Holmes, 1964). Thus, the high rate of dust accumulation in central Alaska is very localized. In contrast, the region of thick $(10-40 \mathrm{~m})$ loess in the Great Plains extends from eastern Colorado to western Iowa, an east-west distance of $500-600 \mathrm{~km}$, with a north-south extent of $100-150 \mathrm{~km}$ (Hallberg et al., 1991; Swinehart et al., 1994; Muhs et al., 1999). Furthermore, detailed isotopic studies show that the dust of the Nebraskan loess deposits originates mainly from a nonglaciogenic source, the Tertiary White River Group siltstone, rather than strictly from the local river systems (Aleinikoff et al., 1998, 1999). This siltstone crops out in eastern Wyoming and Colorado, northern Nebraska and southern South Dakota, several hundred kilometers north of the study localities, suggesting that much of the dust is far traveled.

\section{Discussion}

The high-resolution OSL chronology established at each site allows the calculation of MARs throughout the 25,000$14,000 \mathrm{yr}$ period. Thus, we can estimate variations in dust flux. Despite differences in the thicknesses of the Peoria Loess for the three sections examined in this study, the timing of the maximum MARs during the last glacial period occurs during the same time interval for all three sites. MARs reach unprecedented levels between $\sim 18,000$ and $14,000 \mathrm{yr}$ B.P., with maximum MAR values being more than $50 \%$ higher than the average MARs. Luminescence dating of three loess sections in Nebraska shows that the main period of dust accumulation during the last-glacial period occurred from about 20,000 to $14,000 \mathrm{yr}$ ago, with extremely high accumulation rates in the interval between about 18,000 and $14,000 \mathrm{yr}$ ago.

This $4000 \mathrm{yr}$ period of high dust flux coincides with the timing of one of the largest discrepancies between paleoenvironmental data for central North America and the simulated paleoclimate from atmospheric general circulation models (AGCMs) (Bartlein et al., 1998). In North America, the last glacial period was much cooler than present and 


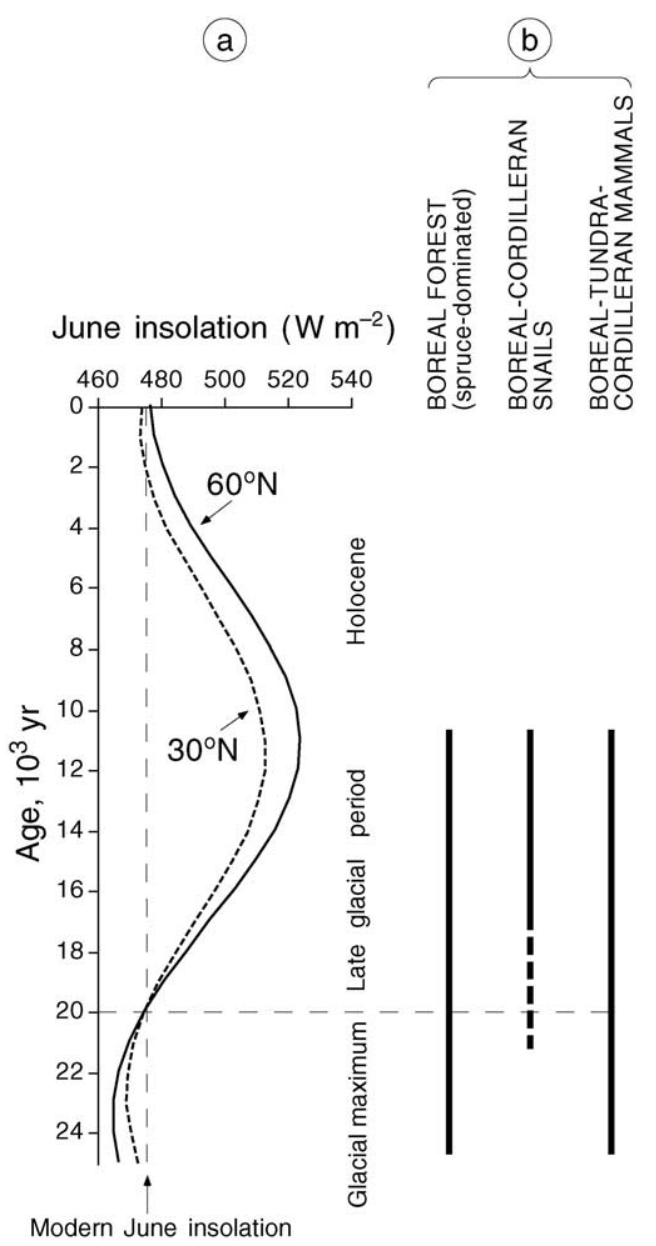

Fig. 3. (a) June insolation at the top of the atmosphere at $30^{\circ} \mathrm{N}$ and $60^{\circ} \mathrm{N}$ for the last 25,000 cal yr B.P. (Berger and Loutre, 1991), (b) times of colder-than-present climate inferred from the presence of spruce macrofossils or pollen, extralimital northern and western land snails, and extralimital northern mammals (data compiled from the following sources: Baker et al., 1986; 1989; 1992; FAUNMAP, 1994; Frye et al., 1974; Leonard, 1951; Leonard and Frye, 1960; Licciardi et al., 1998; Rousseau and Kukla, 1994; Ruhe, 1969; Schwert et al., 1997; Watts, 1983; Webb et al., 1983; Wells and Stewart, 1987; Wright, 1981).

culminated in the buildup of the Laurentide and Cordilleran ice sheets, as well as extensive alpine glaciers in mountainous regions. The last glacial maximum (LGM) coincided with the last minimum in northern hemisphere summer insolation around 24,000 to $22,000 \mathrm{cal} \mathrm{yr}$ (Fig. 3a). There is abundant evidence for a colder climate in the region to the south of the Laurentide Ice Sheet at that time. This evidence includes periglacial features (solifluction, ice-wedge casts, and patterned ground), and both vegetation communities (boreal forest, tundra, or cool steppe) and fauna (beetles, land snails, and mammals) that now occur only in higher latitude or higher altitude regions (Fig. 3b). However, during the late glacial period ( $\sim 20,000$ to $12,000 \mathrm{cal}$ yr B.P.), summer insolation increased to values above those of today (Fig. 3a), yet many cold-climate-adapted plant and animal communities persisted through the period (Figs. 1 and $3 \mathrm{~b}$ ).
These data conflict with the output of AGCMs that have consistently modeled the late-glacial period as being significantly warmer than present in central North America (e.g., Bartlein et al., 1998).

Several mechanisms could be offered to explain the discrepancy between the modeled scenario and the lateglacial paleoclimatic record of central North America. One explanation is that cool ocean waters from the LGM persisted and cooled the adjacent land masses; however, this is unlikely to have affected the study area because central North America is far from any ocean and today has an extremely continental setting. Advection of cool air off the Laurentide Ice Sheet would also have modified the local climate, but AGCMs which incorporate this process (Bartlein et al., 1998; Kutzbach et al., 1998) still fail to predict the magnitude of cooling found in the geological record. Furthermore, the loess record itself shows that winds off the Laurentide Ice Sheet were probably of minimal strength or were limited to a small area south of the ice sheet (Muhs and Bettis, 2000). Given the unprecedented dust accumulation rates identified in this study, a more likely explanation for the discrepancy may relate to the role of dust in atmospheric processes. Traditionally, high rates of dust (loess) deposition were believed to be only the result of climate change, specifically the shift to a dry, cold, windy glacial period with abundant sediment supply and little vegetation cover. Recent climate models have presented an expanded concept, suggesting that increased levels of atmospheric dusthowever they are brought about-can also cause climate change (Overpeck et al., 1996; Tegen et al., 1996; Harrison et al., 2001).

We hypothesize that south of the Laurentide Ice Sheet, the effect of increased summer insolation in late-glacial time may have been offset by the cooling effects of a high dust flux. The effect of airborne dust on radiative transfer processes is a function of particle size, mineralogy, the height of the dust column, and the albedo of the surface over which the particles are transported. Over relatively highalbedo surfaces (e.g., ice sheets, snow-covered landscapes, dune fields, or light-colored bedrock), dust in transport has the effect of warming the lower atmosphere. In contrast, over relatively low-albedo surfaces (ocean, grassland, forest, tundra), radiative scatter from dust cools the lower atmosphere (Tegen et al., 1996). Modeling experiments show that in areas of high dust flux, such as over the Arabian Sea, solar radiation at the Earth's surface can be reduced by as much as $25 \mathrm{~W} \mathrm{~m}^{-2}$ (Harrison et al., 2001; Overpeck et al., 1996; Tegen et al., 1996). This amount of negative forcing is similar to the amplitude of summerinsolation variation since the LGM (Fig. 3a). At the LGM, landscapes south of the Laurentide Ice Sheet were probably covered by tundra, boreal forest, or boreal grassland (Baker et al., 1989; Muhs et al., 1999; Schwert et al., 1997; Wells and Stewart, 1987; Wright, 1981), all of which would have relatively low albedos in summer (McFadden and Ragotz- 
kie, 1967). High atmospheric dust loading over this region may, therefore, be expected to result in cooling.

Particle size is a key variable in the amount of radiative forcing by airborne dust, as smaller particles are more effective in scattering radiation than are large particles. When modeling the effects of dust over the Arabian Sea (Tegen et al., 1996), particle diameters were typically $<20 \mu \mathrm{m}$ and much of the radiative scatter causing the reduction of insolation by $25 \mathrm{~W} \mathrm{~m}^{-2}$ came from particles $<2 \mu \mathrm{m}$ in diameter. Thus, when considering the role of dust in climate forcing for central North America, a simple comparison of MARs between distal and proximal sites would be misleading, because grain-size distribution needs to be taken into account. Both grain size and loess thickness change with distance from a source. In southeastern Nebraska, distant from the probable loess source, the $<2-\mu \mathrm{m}$ fraction typically is $\sim 19 \%$ and the $<20-\mu \mathrm{m}$ fraction is $\sim 43 \%$. In contrast, at Bignell Hill and Devil's Den, closer to the source, these values are $7 \%(<2-\mu \mathrm{m}$ fraction) and $21 \%$ $(<20-\mu \mathrm{m}$ fraction). Nevertheless, for Bignell Hill and Devil's Den, MARs recalculated using only the $<20-\mu \mathrm{m}$ fraction still give values higher than those reported anywhere else in the world, $\sim 2000 \mathrm{~g} \mathrm{~m}^{-2} \mathrm{yr}^{-1}$.

Thus, through radiative forcing, dust may have been a major factor in atmospheric cooling across central North America during the latter part of the last glacial period. Dust-transporting paleowinds were from the west and northwest (Mason, 2001; Muhs and Bettis, 2000) across a lowalbedo vegetated landscape and, therefore, a large region to the south of the Laurentide Ice Sheet could have been affected by radiative backscatter from dust in the atmosphere. Radiative backscatter could have offset the orbitally driven increase in summer insolation following the LGM. As a result, a colder-than-present climate could have been maintained over central North America for several thousand years after summer insolation exceeded present-day values. Our study permits the first direct calculation of stratigraphic variations in dust flux during the last glacial period, revealing unprecedented mass accumulation rates and highlighting the need for AGCMs to incorporate the effect of atmospheric dust loading at a regional scale.

\section{Conclusions}

Optically stimulated luminescence dating of quartz has been applied to three thick last-glacial loess deposits in western Nebraska, midcontinental North America, giving accurate and highly precise ages. These ages show that the onset of Peoria Loess deposition began early during the last glacial maximum at Bignell Hill ( $\sim 25,000$ yr ago), but later at Devil's Den $(\sim 18,000 \mathrm{yr}$ ago $)$ and Eustis $(\sim 21,000 \mathrm{yr}$ ago). At all three sites, Peoria Loess deposition effectively ended some time after $\sim 14,000 \mathrm{yr}$ ago. Based on the OSL ages, average MARs for the last glacial period at all three sites are higher than those reported for any other pre-Holo- cene location in the world. Furthermore, within the sections, calculated MARs show that dust accumulation rates reached unprecedented values at all three sites between 18,000 and $14,000 \mathrm{yr}$ ago. This period of extraordinary dust flux coincides with a mismatch between paleoenvironmental evidence (cool climate) and the output of AGCMs (warm climate). We hypothesize that the unprecedented dust fluxes may be responsible for climatic forcing in central North America at this time, maintaining a colder-than-present climate in the region for several thousand years after summer insolation values exceeded those of the present day. This study highlights the need for dust to be incorporated into climate models.

\section{Acknowledgments}

This study was supported by the Earth Surfaces Dynamics Program of the U.S. Geological Survey and is a contribution to the Eolian Records of North America Project. We thank the landowners, Ken and Emily Wehrman and Kent and Bonnie Hueftle, for generous access to Devil's Den and Eustis, respectively. We also thank Josh Been (U.S. Geological Survey) for assistance in the field, Stephen Stokes (Oxford University) for providing software for the portable gamma spectrometer, and Ina Tegen for valuable informal discussions. Tom Ager and John Aleinikoff (U.S. Geological Survey) read an earlier version of the paper and made helpful comments for its improvement. Glenn Berger (Desert Research Institute, Reno) is thanked for his helpful comments that improved the manuscript at the review stage. Thanks also to the editor and an anonymous reviewer.

\section{References}

Aitken, M.J., 1985. Thermoluminescence Dating. Academic Press, London.

Aitken, M.J., 1998. An Introduction to Optical Dating. Oxford University Press, Oxford.

Aleinikoff, J.N., Muhs, D.R., Fanning, C.M., 1998. Isotopic evidence for the sources of late Wisconsin (Peoria) Loess: implications for paleoclimate, in: Busacca, A. (Ed.), Dust Aerosols, Loess Soils \& Global Change, Washington State University, College of Agriculture and Home Economics Miscellaneous Publication No. MISC0190, Colorado and Nebraska, pp. 124-127.

Aleinikoff, J.N., Muhs, D.R., Sauer, R.R., Fanning, C.M., 1999. Late Quaternary loess in northeastern Colorado. Part II. Pb isotopic evidence for the variability of loess sources. Geological Society of America Bulletin 111, 1876-1883.

Antoine, P., Rousseau, D.-D., Zöller, L., Lang, A., Munaut, A.-V., Hatté, C., Fontugne, M., 2001. High-resolution record of the last interglacialglacial cycle in the Nussloch loess-paleosol sequences, Upper Rhine area, Germany. Quaternary International 76/77, 211-229.

Baker, R.G., Maher, L.J., Chumbley, C.A., Van Zant, K.L., 1992. Patterns of Holocene environmental-change in the Midwestern United-States. Quaternary Research 37, 379-389.

Baker, R.G., Sullivan, A.E., Hallberg, G.R., Horton, D.G., 1989. Vegetational changes in western Illinois during the onset of late Wisconsinan glaciation. Ecology 70, 1363-1376. 
Baker, R.G., Rhodes II, R.S., Schwert, D.P., Ashworth, A.C., Frest, T.J., Hallberg, G.R., Janssens, J.A., 1986. A full-glacial biota from southeastern Iowa, USA. Journal of Quaternary Science 1, 91-107.

Banerjee, D., Murray, A.S., Bøtter-Jensen, L., Lang, A., 2001. Equivalent dose estimation using a single aliquot of polymineral fine grains. Radiation Measurements 33, 73-93.

Bartlein, P.J., Anderson, K.H., Anderson, P.M., Edwards, M.E., Mock, C.J., Thompson, R.S., Webb, R.S., Webb III, T., Whitlock, C., 1998 Paleoclimate simulations for North America over the past 21,000 years: features of the simulated climate and comparisons with paleoenvironmental data. Quaternary Science Reviews 17, 549-585.

Berger, A., Loutre, M.F., 1991. Insolation values for the climate of the last 10 million years. Quaternary Science Reviews 10, 297.

Berger, G.W., Mulhern, P.J., Huntley, D.J., 1980. Isolation of silt-sized quartz from sediments. Ancient TL 11, 8-9.

Bettis III, E.A., Muhs, D.R., Roberts, H.M., Wintle, A.G. 2003. Last Glacial loess in the conterminous U.S.A., Quaternary Science Reviews, in press.

Eden, D.N., Froggatt, P.C., McIntosh, P.D., 1992. The distribution and composition of volcanic glass in late Quaternary loess deposits of southern South Island, New Zealand, and some possible correlations. New Zealand Journal of Geology and Geophysics 35, 69-79.

FAUNMAP Working Group. 1994. FAUNMAP: a Database documenting Late Quaternary distributions of mammal species in the United States. Illinois State Museum Scientific Paper 25.

Frye, J.C., Leonard, A.B., Willman, H.B., Glass, H.D., Follmer, L.R., 1974. Late Woodfordian Jules Soil and associated molluscan faunas. Illinois State Geological Survey Circular 486, 1-11.

Hallberg, G.R., Lineback, J.A., Mickelson, D.M., Knox, J.C., Goebel, J.E., Hobbs, H.C., Whitfield, J.W., Ward, R.A., Boellstorf, J.D., Swinehart, J.B., Dreeszen, V.H., 1991. Quaternary geologic map of the Des Moines $4^{\circ} \times 6^{\circ}$ quadrangle. U.S. Geological Survey Miscellaneous Investigations Series Map I-1420 (NK-15), scale 1:1,000,000.

Harrison, S., Kohfeld, K.E., Roelandt, C., Claquin, T., 2001. The role of dust in climate changes today, at the last glacial maximum and in the future. Earth Science Reviews 54, 43-80.

Hatté, C., Fontugne, M., Rousseau, D.-D., Antoine, P., Zöller, L., TisnératLaborde, N., Bentaleb, I., 1998. $\delta^{13} \mathrm{C}$ variations of loess organic matter as a record of the vegetation response to climatic changes during the Weichselian. Geology 26, 583-586.

Johnson, W.C., 1993. Surficial geology and stratigraphy of Phillips County, Kansas, with emphasis on the Quaternary Period. Kansas Geological Survey Technical Series 1, 66 p.

Johnson, W.C., Willey, K.L., 2000. Isotopic and rock magnetic expression of environmental change at the Pleistocene-Holocene transition in the central Great Plains. Quaternary International 67, 89-106.

Kohfeld, K.E., Harrison, S.P., 2000. How well can we simulate past climates? Evaluating the models using global paleoenvironmental datasets. Quaternary Science Reviews 19, 321-346.

Kohfeld, K.E., Harrison, S.P., 2001. DIRTMAP: the geological record of dust. Earth Science Reviews 54, 81-114.

Kutzbach, J., Gallimore, R., Harrison, S., Behling, P., Selin, R., Laarif, F., 1998. Climate and biome simulations for the past 21,000 years. Quaternary Science Revews 17, 473-506.

Lauriol, B., Cabana, Y., Cinq-Mars, J., Geurts, M.-A., Grimm, F.W., 2002. Cliff-top eolian deposits and associated molluscan assemblages as indicators of Late Pleistocene and Holocene environments in Beringia. Quaternary International 87, 59-79.

Leonard, A.B., 1951. Stratigraphic zonation of the Peoria Loess in Kansas Journal of Geology 59, 323-332.

Leonard, A.B., Frye, J.C., 1960. Wisconsinan molluscan faunas of the Illinois Valley region. Illinois State Geological Survey Circular 304, 1-32.

Licciardi, J.M., Clark, P.U., Jenson, J.W., Macayeal, D.R., 1998. Deglaciation of a soft-bedded Laurentide Ice Sheet. Quaternary Science Reviews 17, 427-448.

Lindholm, G.F., Thomas, L.A., Davidson, D.T., Handy, R.L., Roy, C.J., 1959. Silts near Big Delta and Fairbanks, in: Davidson, D.T., Roy, C.J.
(Eds.), The Geology and Engineering Characteristics of Some Alaskan Soils, Iowa State University Bulletin 186, pp. 33-70.

Maat, P.B., Johnson, W.C., 1996. Thermoluminescence and new ${ }^{14} \mathrm{C}$ age estimates for late Quaternary loesses in southwestern Nebraska. Geomorphology 17, 115-128.

Mahowald, N., Kohfeld, K., Hansson, M., Balkanski, Y., Harrison, S.P., Prentice, I.C., Schulz, M., Rodhe, H., 1999. Dust sources and deposition during the last glacial maximum and current climate: a comparison of model results with paleodata from ice cores and marine sediments. Journal of Geophysical Research-Atmospheres 104, 15895-15916.

Martin, C.W., 1993. Radiocarbon ages on late Pleistocene loess stratigraphy of Nebraska and Kansas, central Great Plains, U.S.A. Quaternary Science Reviews 12, 179-188.

Mason, J.A., 2001. Transport direction of Peoria Loess in Nebraska and implications for loess sources on the central Great Plains. Quaternary Research 56, 79-86.

McFadden, J.D., Ragotzkie, R.A., 1967. Climatological significance of albedo in central Canada. Journal of Geophysical Research 72, 11351143 .

Muhs, D.R., Bettis III, E.A., 2000. Geochemical variations in Peoria Loess of western Iowa indicate paleowinds of midcontinental North America during last glaciation. Quaternary Research 53, 49-61.

Muhs, D.R., Aleinikoff, J.N., Stafford, T.W., Kihl, R., Been, J., Mahan, S.A., Cowherd, S., 1999. Late Quaternary loess in northeastern Colorado. Part I. Age and paleoclimatic significance. Geological Society of America Bulletin 111, 1861-1875.

Musson, F.M., Wintle, A.G., 1994. Luminescence dating of the loess profile at Dolní Vestonice, Czech Republic. Quaternary Geochronology (Quaternary Science Reviews) 13, 411-416.

Nawrocki, J., Bakhmutov, V., Bogucki, A., Dolecki, L., 1999. The paleoand petromagnetic record in the Polish and Ukrainian loess-paleosol sequences. Physics and Chemistry of the Earth 24, 773-777.

Overpeck, J., Rind, D., Lacis, A., Healy, R., 1996. Possible role of dustinduced regional warming in abrupt climate change during the last glacial period. Nature 384, 447-449.

Palmer, A.S., Pillans, B.J., 1996. Record of climatic fluctuations from ca. 500 ka loess deposits and paleosols near Wanganui, New Zealand. Quaternary International 34-36, 155-162.

Péwé, T.L., 1975. Quaternary geology of Alaska. Geological Survey Professional Paper 835.

Péwé, T.L., Holmes, G.W., 1964. Geology of the Mt. Hayes D-4 quadrangle. U.S. Geological Survey Miscellaneous Geologic Investigations Map I-394, scale 1:63,360, Alaska.

Pillans, B., McGlone, M., Palmer, A., Mildenhall, D., Alloway, B., Berger, G., 1993. The Last Glacial Maximum in central and southern North Island, New Zealand: a paleoenvironmental reconstruction using the Kawakawa Tephra Formation as a chronostratigraphic marker. Palaeogeography, Palaeoclimatology, Palaeoecology 101, 283-304.

Prescott, J.R., Hutton, J.T., 1994. Cosmic ray contributions to dose rates for luminescence and ESR dating: large depths and long-term time variations. Radiation Measurements 23, 497-500.

Pye, K., Winspear, N.R., Zhou, L.P., 1995. Thermoluminescence ages of loess and associated sediments in central Nebraska, USA. Palaeogeography, Palaeoclimatology, Palaeoecology 118, 73-87.

Rees-Jones, J., 1995. Optical dating of young sediments using fine-grain quartz. Ancient TL 13, 9-13.

Roberts, H.M., Wintle, A.G., 2001. Equivalent dose determinations for polymineralic fine-grains using the SAR protocol: application to a Holocene sequence of the Chinese Loess Plateau. Quaternary Science Reviews 20, 859-863.

Rousseau, D.-D., Kukla, G., 1994. Late Pleistocene climate record in the Eustis loess section, Nebraska, based on land snail assemblages and magnetic susceptibility. Quaternary Research 42, 176-187.

Ruhe, R.V., 1969. Quaternary Landscapes in Iowa. Iowa State University Press, Ames, IA

Schwert, D.P., Torpen-Kreft, H.J., Hajic, E.R., 1997. Characterization of the Late-Wisconsinan Tundra/Forest Transition in Midcontinental 
North America using assemblages of beetle fossils. Quaternary Proceedings 5, 237-243.

Stuiver, M., Reimer, P.J., Bard, E., Beck, J.W., Burr, G.S., Hughen, K.A., Kromer, B., McCormac, G., Van der Plicht, J., Spurk, M., 1998. INTCAL98 radiocarbon age calibration, 24,000-0 cal BP. Radiocarbon 40, 1041-1083.

Sümegi, P., Rudner, Z.E., 2001. In situ charcoal fragments as remains of natural wild fires in the upper Würm of the Carpathian Basin. Quaternary International 76/77, 165-176.

Sun, J.M., Kohfeld, K.E., Harrison, S.P., 2000. Records of aeolian dust deposition on the Chinese Loess Plateau during the Late Quaternary. Max-Planck Institut für Biogeochemie Technical Report 1.

Swineford, A., Frye, J.C., 1951. Petrography of the Peoria Loess in Kansas. Journal of Geology 59, 306-322.

Swinehart, J.B., Dreeszen, V.H., Richmond, G.M., Tipton, M.J., Bretz, R., Steece, F.V., Hallberg, G.R., Goebel, J.E., 1994. Quaternary geologic map of the Platte River $4^{\circ} \times 6^{\circ}$ quadrangle. U.S. Geological Survey Miscellaneous Investigations Series Map I-1420 (NK-14), scale $1: 1,000,000$.

Swinehart, J.B., Loope, D., Ponte, M., Mason, J., Helland, P., Kim, N., 1994. Paleonenvironments of the Nebraska Sand Hills. Society for Sedimentary Geology, Midcontinent Section, Field Trip Guidebook, University of Nebraska, Lincoln.
Tegen, I., Lacis, A.A., Fung, I., 1996. The influence on climate forcing of mineral aerosols from disturbed soils. Nature 380, 419-422.

Voelker, A.H.L., Grootes, P.M., Nadeau, M.-J., Sarnthein, M., 2000. Radiocarbon levels in the Iceland Sea from 25-53 kyr and their link to the Earth's magnetic field intensity. Radiocarbon 42, 437-452.

Watts, W.A., 1983. Vegetational history of the eastern United States 25,000 to 10,000 years ago, in: Wright Jr., H.E, Porter, S.C. (Eds.), Late-Quaternary Environments of the United States, Vol. 1, The Late Pleistocene (University of Minnesota Press, Minneapolis), pp. 294 310.

Webb III, T., Cushing, E.J., Wright Jr., H.E., 1983. Holocene changes in the vegetation of the midwest, in: Wright Jr., H.E., Porter, S.C. (Eds.), Late-Quaternary Environments of the United States, Vol. 2, The Holocene (University of Minnesota Press, Minneapolis), pp. 142-165.

Wells, P.V., Stewart, J.D., 1987. Spruce charcoal, conifer macrofossils, and landsnail and small-vertebrate faunas in Wisconsinan sediments on the High Plains of Kansas. In Johnson, W.C. Ed. Quaternary Environments of Kansas (Kansas Geological Survey Guidebook Series 5), pp. 129140 .

Wintle, A.G., Shackleton, N.J., Lautridou, J.P., 1984. Thermoluminescence dating of periods of loess deposition and soil formation in Normandy. Nature 310, 491-493.

Wright Jr., H.E., 1981. Vegetation east of the Rocky Mountains 18,000 years ago. Quaternary Research 15, 113-125. 